\title{
NITRATE ACCUMULATION IN LETTUCE AND ROCKET IN RESPONSE TO NITROGEN FERTILIZATION IN INTERCROPPING ${ }^{1}$
}

\author{
AURÉLIO PAES BARROS JÚNIOR ${ }^{2}$, ARTHUR BERNARDES CECÍLIO FILHO ${ }^{3}$, BRÁULIO LUCIANO ALVES \\ REZENDE ${ }^{4}$, HAMURÁBI ANIZIO LINS ${ }^{2 *}$
}

\begin{abstract}
In the cultivation of leafy vegetables, it is common to apply high amounts of nitrogen fertilizer. The imbalance between the absorption and the use of nitrogen $(\mathrm{N})$ by the plant increases the nitrate content and decreases the quality of the vegetables because nitrate has a strong association with compounds harmful to human health. On the other hand, there is a lack of information on how $\mathrm{N}$ dose in intercropping, in order to improve yield, affects the quality (nitrate content) of vegetables. Thus, the objective of this study was to evaluate the nitrate content of intercropped lettuce and rocket, with nitrate content acting as a function of the nitrogen dose applied to these crops. The experiment was carried out at UNESP, Jaboticabal, SP, from September to December 2006. The experimental design was a complete randomized block design with four replications. The treatments were arranged in a $4 \times 4+2$ factorial scheme, with four varying concentrations of $\mathrm{N}$ each for lettuce and rocket $\left(0,65,130\right.$ and $195 \mathrm{~kg} \mathrm{ha}^{-1}$ of $\left.\mathrm{N}\right)$, plus two treatments corresponding to lettuce and rocket monocrops. Nitrate content in lettuce under intercropping is $42 \%$ less compared to that in the monocrop. Increasing nitrogen concentrations increased nitrate levels for lettuce and rocket under intercropping; however, these levels are below those found for their respective monocrops.
\end{abstract}

Keywords: Lactuca sativa. Eruca sativa. System of cultivation and nutritional quality.

\section{ACÚMULO DE NITRATO NA ALFACE E RÚCULA EM RESPOSTA À ADUBAÇÃO NITROGENADA DAS CULTURAS EM CONSÓRCIO}

\begin{abstract}
RESUMO - No cultivo de hortaliças folhosas é comum a aplicação de elevadas quantidades de fertilizante nitrogenado. $\mathrm{O}$ desequilíbrio entre a absorção e o uso do nitrogênio $(\mathrm{N})$ pela planta eleva o teor de nitrato e diminui a qualidade das hortaliças, pois tem forte associação com compostos prejudiciais à saúde humana. Por outro lado, há falta de informação para dose de $\mathrm{N}$ em cultivos consorciados com vistas à obtenção de boa produtividade e como isso impacta a qualidade (teor de nitrato) das hortaliças. Sendo assim, o objetivo desse estudo foi avaliar o teor de nitrato na alface e na rúcula, em função da dose de nitrogênio aplicada às culturas em cultivo consorciado. O experimento foi conduzido na UNESP, Jaboticabal, SP, de setembro a dezembro de 2006. O delineamento experimental foi o de blocos casualizados completos, com quatro repetições, sendo os tratamentos arranjados em esquema fatorial $4 \times 4+2$. Os tratamentos resultaram da combinação de quatro doses de $\mathrm{N}$ para a alface $\left(0,65,130\right.$ e $195 \mathrm{~kg} \mathrm{ha}^{-1}$ de $\left.\mathrm{N}\right)$ e quatro doses de $\mathrm{N}$ para a rúcula $(0,65,130$ e $195 \mathrm{~kg}$ $\mathrm{ha}^{-1}$ de $\mathrm{N}$ ), mais dois tratamentos adicionais correspondentes às monoculturas de alface e rúcula. $\mathrm{O}$ teor de nitrato na cultura da alface em consórcio reduziu $42 \%$ quando comparado à monocultura. $\mathrm{O}$ aumento das doses de nitrogênio, para ambas as culturas em consórcio, resulta em aumento nos teores de nitrato para alface e rúcula; porém, abaixo dos encontrados para suas respectivas monoculturas.
\end{abstract}

Palavras-chave: Lactuca sativa. Eruca sativa. Sistema de cultivo e qualidade nutricional.

\footnotetext{
${ }^{*}$ Corresponding author

${ }^{1}$ Received for publication in $06 / 12 / 2019$; accepted in 09/04/2019.

Paper extracted from the doctoral thesis of the first author.

${ }^{2}$ Department of Agronomic and Forest Sciences, Universidade Federal Rural do Semi-Árido, Mossoró, RN, Brazil; aurelio.barros@ufersa.edu.br - ORCID: 0000-0002-6983-8245, hamurabi a @ hotmail.com - ORCID: 0000-0002-4548-9108.

${ }^{3}$ Department of Plant Production, Universidade Estadual Paulista Júlio de Mesquita Filho, Jaboticabal, SP, Brazil; rutra@fcav.unesp.br ORCID: 0000-0002-6706-5496.

${ }^{4}$ Department of Plant Production, Instituto Federal de Educação, Ciência e Tecnologia do Sul de Minas Gerais, Muzambinho, MG, Brazil; blrezende76@gmail.com - ORCID: 0000-0001-9678-5778.
} 


\section{INTRODUCTION}

Intercropping, or mixed cropping is defined as the cultivation of two or more crops of different cycle and/or architecture simultaneously in the same area, with the products harvested not necessarily at the same time, i.e., they cohabit for at least a significant part of their cultivation cycle (LIMA et al., 2013).

Considering that in general vegetables present a very slow initial growth and vary greatly in size, architecture, growth rate, land occupation, and cycle, among other characteristics, it was hypothesized that higher food production per unit area could be obtained by cultivating two or more vegetables in the same area. Thus, this method could potentially improve the way vegetables are produced, especially effective at lowering environmental impact and increasing the profitability of agricultural activity (LINHARES et al., 2013).

In olive growing, the intercropping method has the potential for widespread use by small producers, being a viable and easy technique to implement (PORTO et al., 2011). According to the Food Agricrop Organization (FAO) (FAO, 2014), more than $75 \%$ of vegetable production in Brazil comes from family farming. In the southern and southeastern regions of Brazil, vegetable production is largely carried out by the partnership between land owner and farming families.

The viability of lettuce and rocket intercropping was confirmed by Nascimento, Nascimento e Cecílio Filho. (2018), Bezerra Neto et al. (2012), and Oliveira et al. (2010). However, due to a lack of knowledge regarding the nitrogen $(\mathrm{N})$ requirement for both crops, a factor modified by the coexistence of species (BARROS JÚNIOR et al., 2011), the fertilization concentration used for intercropping is empirically based on the recommended nutrient doses for monocrops.

The nitrogen fertilization promotes productivity, excessive use can lead to a decrease in food quality. Nitrate accumulation in plants occurs when there is an imbalance between ion absorption and assimilation, and excess in ion amounts are stored in vacuoles. A high nitrate content is considered by many researchers as a major concern, as it can cause serious human health problems (BAIRD; CANN, 2011; KESZEI et al., 2013). Of the total nitrate intake of humans, about $80 \%$ comes from vegetables (TEMME et al., 2011), and may reach over $90 \%$ with consumption of lettuce (IAMMARINO; DI TARANTO; CRISTINO, 2014).

Nitrate tolerance limits are not well defined and are very divergent between researchers. FAO and the World Health Organization (WHO) considered a daily dose of $3.65 \mathrm{mg}$ nitrate ion and $0.133 \mathrm{mg}$ nitrite ion per kilogram of human body mass (FAO/WHO, 2013) to be permissible.

Although it has many advantages over monocrops, intercrop vegetables still require more research into improved management practices. Of the many factors important to intercrop management, the fertilization of the crops is highly relevant because it impacts the growth and productivity of the crops, as well as the quality of the harvested products. Therefore, the objective of this work was to evaluate the nitrate content in lettuce and rocket, as a function of the nitrogen concentration applied to intercropped crops.

\section{MATERIAL AND METHODS}

The experiment was conducted in the field at the Universidade do Estado de São Paulo (UNESP), Jaboticabal, São Paulo, with geographical coordinates $21^{\circ} 14^{\prime} 05^{\prime \prime}$ South, $48^{\circ} 17^{\prime} 09^{\prime \prime}$ West, at an altitude of $614 \mathrm{~m}$. The climate, according to the Köppen classification, is Aw type transitioning into Cwa.

The experimental design was a randomized block design with four replications. The treatments were arranged in a $4 \times 4+2$ factorial scheme. The treatments were based on four nitrogen concentrations $\left(0,65,130\right.$ and $\left.195 \mathrm{~kg} \mathrm{ha}^{-1}\right)$ on lettuce and rocket, plus two additional treatments that correspond to lettuce and rocket monocrops. Doses were based on the recommendation of Trani, Passos e Azevedo Filho (1997), at 130 and $160 \mathrm{~kg} \mathrm{ha}^{-1}$ of $\mathrm{N}$ for lettuce and rocket, respectively.

The experimental unit consisted of 38 monocrop lettuce plants, cultivated with a spacing of $0.30 \times 0.25 \mathrm{~m}$ with a total area of $2.88 \mathrm{~m}^{2}(1.20 \times$ $2.40 \mathrm{~m})$. The experimental unit for rocket cultivation consisted of 107 monocrop plants cultivated with a spacing of $0.25 \times 0.05 \mathrm{~m}$, with a total of 192 plants. In the consortia, the rocket was sown in furrows, located halfway between the lettuce plants. In this cropping system, lettuce was considered the main crop and rocket the secondary crop. In the intercrops, the rocket was sown in furrows located in half of the lettuce rows. In this cropping system, lettuce was considered the main crop and rocket the secondary.

The soil of the area, according to the classification of EMBRAPA (2018), corresponds to Typical Eutroferric Red Latosol with a very clayey texture, moderately kaolinitic-oxidic, with a smooth undulating relief. Soil chemical analysis showed a $\mathrm{pH}\left(\mathrm{CaCl}_{2}\right)$ of $5.6 ; 22 \mathrm{~g} \mathrm{dm}^{-3}$ of organic matter, 147

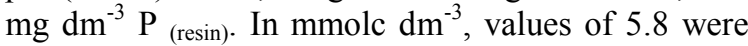
obtained; 40 and 16 of $\mathrm{K}, \mathrm{Ca}$, and $\mathrm{Mg}$, respectively; and $\mathrm{V} \%=67$.

After soil preparation, the beds were prepared. Liming was performed to raise base saturation to $80 \%$ using dolomitic limestone, with Relative Power of Total Neutralization (RPTN) equal to $120 \%$. For initial planting fertilization, 50 $\mathrm{kg} \mathrm{ha}^{-1} \mathrm{~K}_{2} \mathrm{O}$ and $200 \mathrm{~kg} \mathrm{ha}^{-1} \mathrm{P}_{2} \mathrm{O}_{5}$ were applied to all experimental units. For the application of $\mathrm{N}, 30 \%$ of 
the total dose was applied before transplantation or sowing of the crops. The remaining $70 \%$ of the total $\mathrm{N}$ of each dose was divided across three seasons: 10 , 20 and 30 days after transplantation for lettuce (DAT) and 7, 14 and 21 days after sowing (DAS) for rocket, as recommended by Trani, Passos e Azevedo Filho (1997). A mixture of granules with commercial formula of $12 \% \mathrm{~N} \mathrm{ha}^{-1}$ (ammonium nitrate), $6 \% \mathrm{~K}_{2} \mathrm{O}$ $\mathrm{ha}^{-1}$ (potassium chloride) and $12 \% \mathrm{P}_{2} \mathrm{O}_{5} \mathrm{ha}^{-1}$ (single superphosphate) was used as fertilizer. In the monocrops, in addition to the application of the same type and quantity of fertilizers as used for the intercrops, 130 and $160 \mathrm{~kg} \mathrm{ha}^{-1}$ of $\mathrm{N}$ were applied to lettuce and rocket, respectively.

The 'Verônica' lettuce was sown on September 26, 2006, in 288 cell expanded polystyrene trays with Plantmax $\mathrm{HA}^{\circledR}$ substrate. The seedlings were transplanted when they had four leaves in addition to cotyledonary leaves. This occurred on October $30^{\text {th }}, 2006,34$ days after sowing. On the same day as the lettuce transplantation, the 'Folha Larga' rocket was sown directly into the flowerbed, and thinning was performed at $10 \mathrm{DAS}$, to adjust the spacing between plants in the row.

During the experiment, weed control was carried out by hand weeding. Phytosanitary treatments were also performed when necessary. Irrigation was provided by a sprinkler system.

The rocket harvest took place on November $30^{\text {th }}, 2006$, at 31 DAS; and lettuce on December $2^{\text {nd }}$, 2006 , at 33 DAT.

To evaluate the characteristics of lettuce in monocrop or a consortium, we considered the four plant lines as a functional plot, excluding the first and last plants of each line. To evaluate the characteristics of rocket in the monocrop, the two central lines were considered as a functional plot, excluding $0.30 \mathrm{~m}$ from the beginning and end of each line. In the consortium, the three rocket lines between the lettuce rows were considered, and the initial and final $0.30 \mathrm{~m}$ of each row was disregarded.

On the day of harvest, between 5 and 6 am, two freshly developed leaves per plant were collected from three plants within the plot's central lines. The leaves were washed and placed in paper bags to dry in a forced-air greenhouse at around $65^{\circ}$ $\mathrm{C}$ until they reached constant weight. They were then ground in a Willey type mill (MANTOVANI; FERREIRA; CRUZ, 2005). To obtain the leaf extract, the methodology described by Cavarianni
(2004) was used. Nitrate content was determined according to the methodology described by Cataldo et al. (1975). Nitrate content was expressed in grams of nitrate per kilogram of the dry mass of lettuce and rocket.

An analysis of variance (ANOVA) was performed by the F test, using ESTAT software, made by the Department of Exact Sciences of UNESP, Jaboticabal, SP. In the ANOVA, for the characteristics of each crop, the factorial scheme $4 \times$ $4+1$ ( +1 being the additional treatment of lettuce or rocket monocrop) was taken into account. However, independent of the significance of the interaction of the factors in ANOVA, a quadratic polynomial response surface study was performed. When significant, the $F$ test $(p<0.05)$ was used to study the interaction of factors. The Statistica ${ }^{\circledR}$ version 7 software was used to make the graphics.

\section{RESULTS AND DISCUSSION}

There was a difference in nitrate content between monocrop (control) and intercropping (factorial) for lettuce, but not for rocket. The nitrate content of lettuce in monocrop was higher than in intercropping, which is possibly due to competition in the absorption of nutrients between species in the intercropping system. Another explanation for the lower nitrate content in the intercropping group is the way of comparing the groups, with the monocrop being compared to the average of the intercropping (factorial). In general, the application of low doses of the consortium $\mathrm{N}$ contribute to the low nitrate content.

Owing to the interaction between lettuce and rocket intercropping, the nitrate content in lettuce was reduced by $42 \%$ when compared to the control (monocrop). Bezerra Neto et al. (2012) reported that the consortium has a significant advantage over monocrop in terms of production and land use. A lower nitrate content in intercropped lettuce plants is therefore relevant due to the corresponding increase in quality.

The interaction of factors influenced the lettuce and rocket nitrate contents (Figure 1 and Figure 2). In the characteristics evaluated, surface adjustments of quadratic polynomial responses as a function of the nitrogen doses studied for each crop were obtained. 


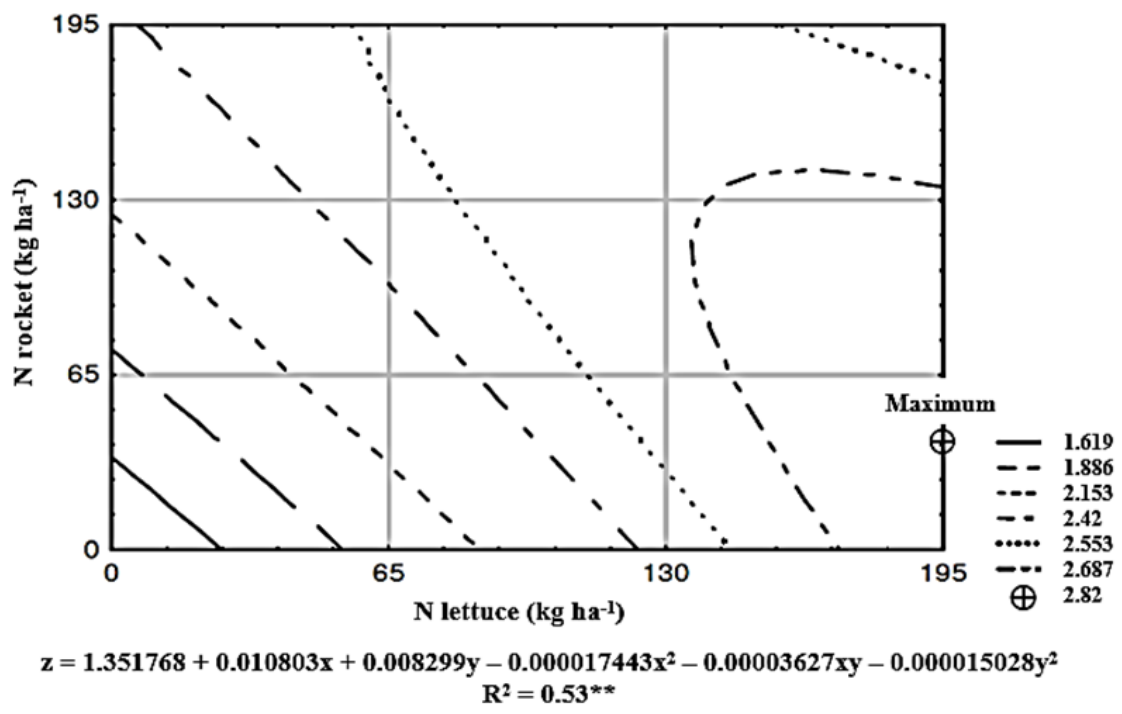

Figure 1. Isolines of the response surface for nitrate content ( $\mathrm{g} \mathrm{kg}^{-1}$ of dry mass) of lettuce intercropped with rocket, as a function of nitrogen concentration.

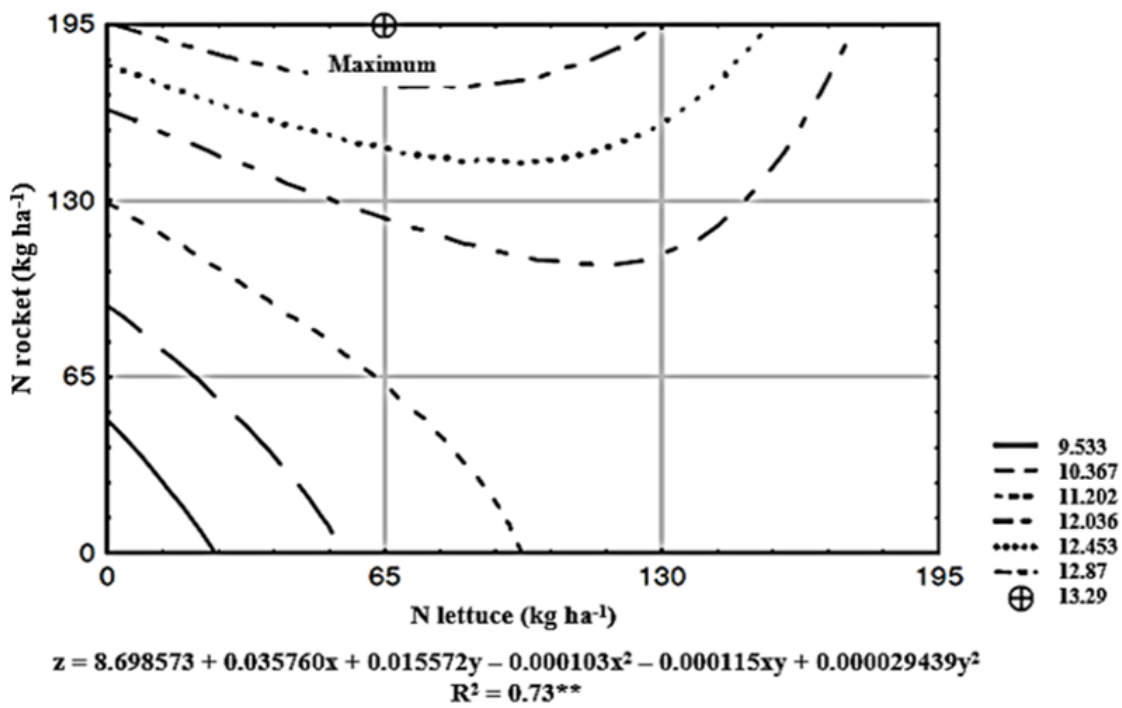

Figure 2. Isolines of the response surface for nitrate content ( $\mathrm{g} \mathrm{kg}^{-1}$ dry mass) of rocket in consortium with lettuce, as a function of nitrogen concentration.

One of the main factors determining the increase of nitrate content in plants is nitrogen fertilization (FONTES; ARAUJO, 2007). Seconddegree polynomial adjustment was observed for lettuce nitrate content, obtained in response to $\mathrm{N}$ rates for lettuce. This result differs from that observed by Mantovani, Ferreira e Cruz (2005), Brkić et al. (2017), and Iammarino, Di Taranto e Cristino (2014), who found a linear and positive nitrate adjustment in five cultivars by increasing the $\mathrm{N}$ dose. When $\mathrm{N}$ fertilization was not performed for both crops, the nitrate content was $1.35 \mathrm{~g} \mathrm{~kg}^{-1}$ of the dry mass, a value that was $52 \%$ lower than the maximum found (Figure 1). The highest leaf nitrate content in lettuce leaves $\left(2.82 \mathrm{~g} \mathrm{~kg}^{-1}\right.$ dry mass) was observed with a fertilizer concentration of $195 \mathrm{~kg} \mathrm{ha}^{-1} \mathrm{~N}$ for lettuce and $41 \mathrm{~kg} \mathrm{ha}^{-1} \mathrm{~N}$ for rocket
(Figure 1). This corresponds to $0.17 \mathrm{~g} \mathrm{~kg}^{-1}$ in fresh mass, which is well below the maximum acceptable limit established by the European community $(2.50 \mathrm{~g}$ $\mathrm{kg}^{-1}$ fresh mass) (WEIGHTMAN; HUDSON, 2013). In monocrop, lettuce that was fertilized with $130 \mathrm{~kg} \mathrm{ha}^{-1}$ of $\mathrm{N}$, presented a nitrate content of 4.10 $\mathrm{g}$ per kilogram of dry mass, which was $45 \%$ higher than the maximum obtained by intercropping.

The maximum nitrate content of rocket was $13.29 \mathrm{~g} \mathrm{~kg}^{-1}$ of dry weight and was obtained with the treatment of fertilizer at a concentration of $195 \mathrm{~kg} \mathrm{ha}^{-1}$ of $\mathrm{N}$ for rocket and $65 \mathrm{~kg} \mathrm{ha}^{-1}$ of $\mathrm{N}$ for lettuce (Figure 2). The maximum obtained was 1.966 $\mathrm{mg} \mathrm{kg}^{-1}$ nitrate in the fresh mass of rocket. The observed content is similar to that obtained by Trani et al. (1994), who observed a quadratic polynomial adjustment of rocket nitrate content with increasing 
$\mathrm{N}$ concentration. In that study, the maximum nitrate content was $10.7 \mathrm{~g} \mathrm{~kg}^{-1}$ of the dry matter, with a fertilizer concentration of $278 \mathrm{~kg} \mathrm{ha}^{-1} \mathrm{~N}$. In the literature consulted, there is no appropriate nitrate content range in rocket leaves. The maximum dry weight content is $0.93 \mathrm{~g} \mathrm{~kg}^{-1}$ of fresh mass, which is below the European Community tolerable ceiling of $2.50 \mathrm{~g} \mathrm{~kg}^{-1}$ of fresh mass (WEIGHTMAN; HUDSON, 2013). It should be noted, however, that rocket accumulated much more nitrate per unit of dry mass than lettuce (Figures 1 and 2).

\section{CONCLUSIONS}

Nitrate content in lettuce leaves under intercropping is $42 \%$ less than monocropping.

Increasing nitrogen concentration for both intercropping yields increased nitrate levels for lettuce and rocket; however, these nitrate levels are still below those found in their respective monocrops.

\section{REFERENCES}

BAIRD, C.; CANN, M. Química Ambiental. 4. ed. Porto Alegre, RS: Bookman, 2011. 844 p.

BARROS JÚNIOR, A. P. et al. Nitrogen fertilization on intercropping of lettuce and rocket. Horticultura Brasileira, 29: 398-403, 2011.

BEZERRA NETO, F. et al. Assessment of agroeconomic indices in polycultures of lettuce, rocket and carrot through uni and multivariate approaches in semi-arid Brazil. Ecological Indicators, 14: 11-17, 2012.

BRKIĆ, D. et al. Nitrate in leafy green vegetables and estimated intake. African Journal of Traditional, Complementary and Alternative medicines, 14: 31-41, 2017.

CATALDO, D. A. L. et al. Rapid colorimetric determination of nitrate in plants tissue by nitration of salicylic acid. Communications in Soil Science and Plant Analysis, 6: 71-90, 1975.

CAVARIANNI, R. L. Produção de cultivares de rúcula no sistema NFT e teores de nitrato. 2004. 42 f. Dissertação (Mestrado em Agronomia/ Produção Vegetal: Área de Concentração em Produção Vegetal) - Universidade Estadual Paulista Júlio de Mesquita Filho, Jaboticabal, 2004.

EMPRESA BRASILEIRA DE PESQUISA AGROPECUÁRIA - EMBRAPA. Sistema
Brasileiro de Classificação de Solos. 5. ed. Brasília, DF: Embrapa, 2018. 531 p.

ORGANIZAÇÃO DAS NAÇÕES UNIDAS PARA ALIMENTAÇÃO E AGRICULTURA - FAO/WHO. Nitrate (and potential endogenous formation of $\mathrm{N}$ nitroso compounds). In: WHO Food Additive series World Health Organization, Geneva, 2013, 50 p.

ORGANIZAÇÃO DAS NAÇÕES UNIDAS PARA ALIMENTAÇÃO E AGRICULTURA - FAO. The State of Food Insecurity in the World 2014. Strengthening the enabling environment for food security and nutrition. Rome, FAO. 2014. Disponível em: <http://www.fao.org/publications/sofi/2014/en/ >. Acesso em: 21 apr. 2019.

FONTES, P. C. R.; ARAUJO, C. Adubação nitrogenada de hortaliças. Viçosa, MG: UFV, 2007. 148 p.

IAMMARINO, M; DI TARANTO, A.; CRISTINO M. Monitoring of nitrites and nitrate levels in leafy vegetables (spinach and lettuce): a contribution to risk assessment. Journal of the Science of Food and Agriculture, 15: 773-778, 2014.

KESZEI, A. P. et al. Dietary N-nitroso compounds, endogenous nitrosation, and the risk of esophageal and gastric cancer subtypes in the Netherlands Cohort Study. American Journal of Clinical Nutritionn, 97: 135-146, 2013.

LIMA, J. S. S. et al. Produtividade da cenoura, coentro e rúcula em função de densidades populacionais. Revista Verde de Agroecologia e Desenvolvimento Sustentável, 8: 110-116, 2013.

LINHARES, P. C. F. et al. Otimização da quantidade de jitirana incorporada ao solo no rendimento do rabanete. Agropecuária Científica no Semiárido, 9: 42-48, 2013

MANTOVANI, J. R.; FERREIRA, M. E.; CRUZ, M. C. P. Produção de alface e acúmulo de nitrato em função da adubação nitrogenada. Horticultura Brasileira, 23: 758-762, 2005.

NASCIMENTO, C. S.; NASCIMENTO, C. S.; CECÍLIO FILHO, A. B. Economic feasibility of lettuce intercropped with rocket in function of spacing and growing season. Revista Caatinga, 31: 106-116, 2018.

OLIVEIRA, E. Q. et al. Produtividade de alface e rúcula, em sistema consorciado, sob adubação orgânica e mineral. Horticultura Brasileira, 28: 3640, 2010.

PORTO V. C. N. et al. Combination of lettuce and 
rocket cultivars in two cultures intercropped with carrots. Horticultura Brasileira, 29: 404-411, 2011.

WEIGHTMAN, R. M.; HUDSON, E. M. Noxious or nutritious? Progress in controlling nitrate as a contaminant in leafy crop species. Food and Energy Security, 2: 141-156, 2013.

TEMME, E. H. et al. Average daily nitrate and nitrite intake in the Belgian population older than 15 years. Food additives \& contaminants. Part A, Chemistry, analysis, control, exposure \& risk assessment, 28: 193-204, 2011.

TRANI, P. E. et al. Produção e acúmulo de nitrato pela rúcula afetados por doses de nitrogênio. Horticultura Brasileira, 12: 25-29, 1994.

TRANI, P. E.; PASSOS, F. A.; AZEVEDO FILHO, J. A. Alface, almeirão, chicória, escarola, rúcula e agrião d'agua. In: RAIJ, B. et al. Recomendação de adubação e calagem para o estado de São Paulo. Campinas, SP: Instituto Agronômico e Fundação IAC, 1997. v. 2, p. 168- 169. 